\title{
Assessing Adoption of New Communication Technologies for Co- Operative Development in Kenya
}

\author{
Mwongela Francis*, Wenje Peres, Anyonje Lydia, John Kirimi M'Raiji \\ Masinde Muliro University of Science and Technology
}

*Corresponding Author: Mwongela Francis, Masinde Muliro University of Science and Technology

\begin{abstract}
New Media Technologies, arguably, are reshaping modern day public lives and business ventures by transforming and expanding the scopes of new potential networks and deepening existing networks and creating a more consistent communication pattern across the globe beating aspects of time and space; to date, ICT has liberalized the business environment world over. The Co-operative sector as an enterprise, has had a long tradition especially in Africa in low uptake of ICTs in their operations. This assertion has arguably affected operations and efficacy of co-operatives making them prone to financial mismanagements, among others. For the co-operative movement to rejuvenate itself in the New Technology era, adoption of ICTs may not be an option. This paper's objective is to find out the extent to which the co-operative economies have adopted ICTs in their operations for growth. This paper relied on secondary data and used qualitative research design. The study found out that to a large extent, cooperatives have adopted new media technologies in their operations. However, more intervention measure need to be employed to make these technologies of value to co-operatives.
\end{abstract}

Keywords: Internet, communication, exploratory, digital divide, ICTs, networks

\section{INTRODUCTION}

Co-operatives in Kenya have had low uptake of ICTs to streamline their communications and enhance their growth compared to other business ventures. This low use of new communication technologies, and business ideas involving Information Communication Technologies (ICTs) are being taken on by corporations and individual business people; a missed opportunity for the co-operative movement in Africa (Nyaga, 2014). In Africa, Kenya's cooperative business model is the best and $7^{\text {th }}$ best in the Globe. (ICA, 2014).

Various arguments have been staged on the numerous benefits of adopting new communication technologies in cooperatives. For instance, cooperatives can cultivate new markets by reaching out to different customer bases online; further, they can keep up-to-date with developments and new innovations and receive training remotely. Such can transform the management of co-operatives by improving, communication, marketing and management practices, financial information and reporting and records management as well as create an online presence. These improvements help increase efficiency and lower operating costs (Tom, 2015).

Drawing a clear example from the Kenya's electronic money transfer system, "M-PESA", based on SMS messaging is said to have changed the lives of millions of Kenyans including the rural poor and liberalized mobile money transfer in Kenya pitting the nation as the leader in the world. (FSD, 2015)

In June 2012, UN argued that, "ICT's are transforming co-operatives by expanding the scope of potential networks and deepening existing networks through more consistent communication."): it was further noted by the UN that Co-operatives are a clearly identifiable group with an existing community of over a billion people and growing. They have unifying cooperative principles which keep their members in a cohesive and coherent union (UN, 2012).

Co-operatives in Kenya have failed to create more jobs and eradicate poverty due to low uptake of new communication technologies. To be a key driver in this, uptake of New Communication technologies is key (Nyaga, 2014). Across the world, co-operatives are gearing up to internet ownership a fact that perhaps may leave African co-operatives behind in the future of co-operatives. 
This new dimension of internet platforms and case in point 'platform cooperativism' will challenge the corporate sharing economy online (Tom, 2015).

\subsection{Adoption of New Communication Technologies by Cooperatives}

Concerns have been raised over the low uptake and adoption of new communication technologies by cooperatives as a booster towards the digital economy being embraced across the globe thus creating a huge entrepreneurial gap among members of co-operatives. This has created a debate on the potential of the new communication technologies in development and growth of cooperatives (Nyaga, 2014).

Emerging new technologies and digital apps including platform cooperativism may not have had a way into the co-operative sector in Kenya. Whereas ICT remains a key component in all sectors of the economy and remains a key driver of businesses and enterprises in the digital world, its uptake among other sectors of the economy across Africa has had significant in positive growth of those sectors a case in point the banking sector and the mobile money transfer services like Mpesa in Kenya which is a recent development compared to the existence of the co-operative sector; This disparity is a case in point which requires address (Wanyama, 2014).

The extent to which new communication technologies can change business operations and the bottom line in the co-operative sector in a year in Kenya and around the world is undisputed (KNBS, 2016). Even, day-to-day business operating systems such as online accounting software are moving to the cloud; flexibility like this allows business owners to process invoices and manage cash flow on the go (Tom, 2015).

\section{Methodology}

This was a qualitative study. The study adopted an exploratory research design. An exploratory design is conducted when a research problem has few or no earlier studies to refer to or rely upon to predict an outcome (McGregor \& Murnane 2010). The focus of the researcher in this study was on gaining insights and familiarity for later investigation or more studies in the area. This design helped establish an understanding of how best to proceed in studying the issues in future and or what methodology would effectively apply to gathering information about the area of study (Taylor \& Bogdan 1998).

The researchers in adopting exploratory research for this study aimed: to gain Familiarity with basic details, settings, and concerns, to get well-grounded picture of the situation to generate new ideas and assumptions for future studies, to determine whether a study is feasible in the future to get direction for future research and techniques (McGregor \& Murnane 2010).

Exploratory research design is a useful approach for gaining background information on a particular topic, it is flexible and can address research questions of all types (what, why, how). It also provides an opportunity to define new terms and clarify existing concepts. Further, an exploratory research is often used to generate formal hypotheses and develop more precise research problems. In the policy arena or applied to practice, exploratory studies help establish research priorities and where resources should be allocated (Taylor \& Bogdan 1998).

However, an exploratory research generally utilizes small sample sizes and, thus, findings are typically not generalizable to the population at large. Further, an exploratory nature of the research inhibits an ability to make definitive conclusions about the findings. They provide insight but not definitive conclusions. The research process underpinning exploratory studies is flexible but often unstructured, leading to only tentative results that have limited value to decision-makers (McGregor \& Murnane 2010).

\section{STUDY FINDINGS AND Discussions}

This section presents data analysis, interpretation and discussion of the research findings. This section looks at the communication process of cooperatives, explores the efficacy of the channels of communication, and explores the ICT infrastructure in a cooperatives.

The study findings are on the adoption of New Communication Technologies for Co-operative Development in Kenya. The data was gathered exclusively from the questionnaire as the research instrument. 


\subsection{Co-Operatives Effectiveness in Communicating with the Publics}

According to the respondents, on the co-operatives' communication to the staff $41 \%$ indicated very good, $23 \%$ cited good, $15 \%$ indicated excellent, $14 \%$ stated average, $4 \%$ poor and $3 \%$ below average. On the co-operatives communication to the heads of department, $32 \%$ cited good, $20 \%$ average, $20 \%$ very good, $13 \%$ excellent, $9 \%$ poor and $6 \%$ below average. On top management communication, $31 \%$ indicated very good, $20 \%$ average, $15 \%$ good, $14 \%$ excellent, $14 \%$ poor and $6 \%$ below average. On board of management director's communication, $40 \%$ cited average, $20 \%$ excellent, $18 \%$ very good, $11 \%$ below average, $9 \%$ poor and $2 \%$ average. On shareholders communication $38 \%$ cited very good, $22 \%$ average, $13 \%$ below average, $10 \%$ poor, $10 \%$ good and $7 \%$ excellent. On regulatory body's communication, $50 \%$ cited very good, $30 \%$ excellent, $7 \%$ below average, $6 \%$ good, $4 \%$ poor and $3 \%$ average. On the government communication, $40 \%$ indicated very good, $25 \%$ average, $20 \%$ poor, $6 \%$ good, $6 \%$ excellent and 3\% below average. On potential shareholders communication, $40 \%$ indicated good, $20 \%$ average, $14 \%$ very good, $11 \%$ excellent, $10 \%$ below average and $5 \%$ poor. Lastly, on customer's communication, $44 \%$ cited very good, $20 \%$ excellent, $14 \%$ good, $8 \%$ below average $6 \%$ average and $6 \%$ poor.

From the above findings, the researchers can deduce that co-operative societies are above average in communicating with their various key publics. It is prudent for researchers to conclude that cooperative societies internal communications are well managed. However, externally, there seems to be a challenge that perhaps calls for further studies in this area.

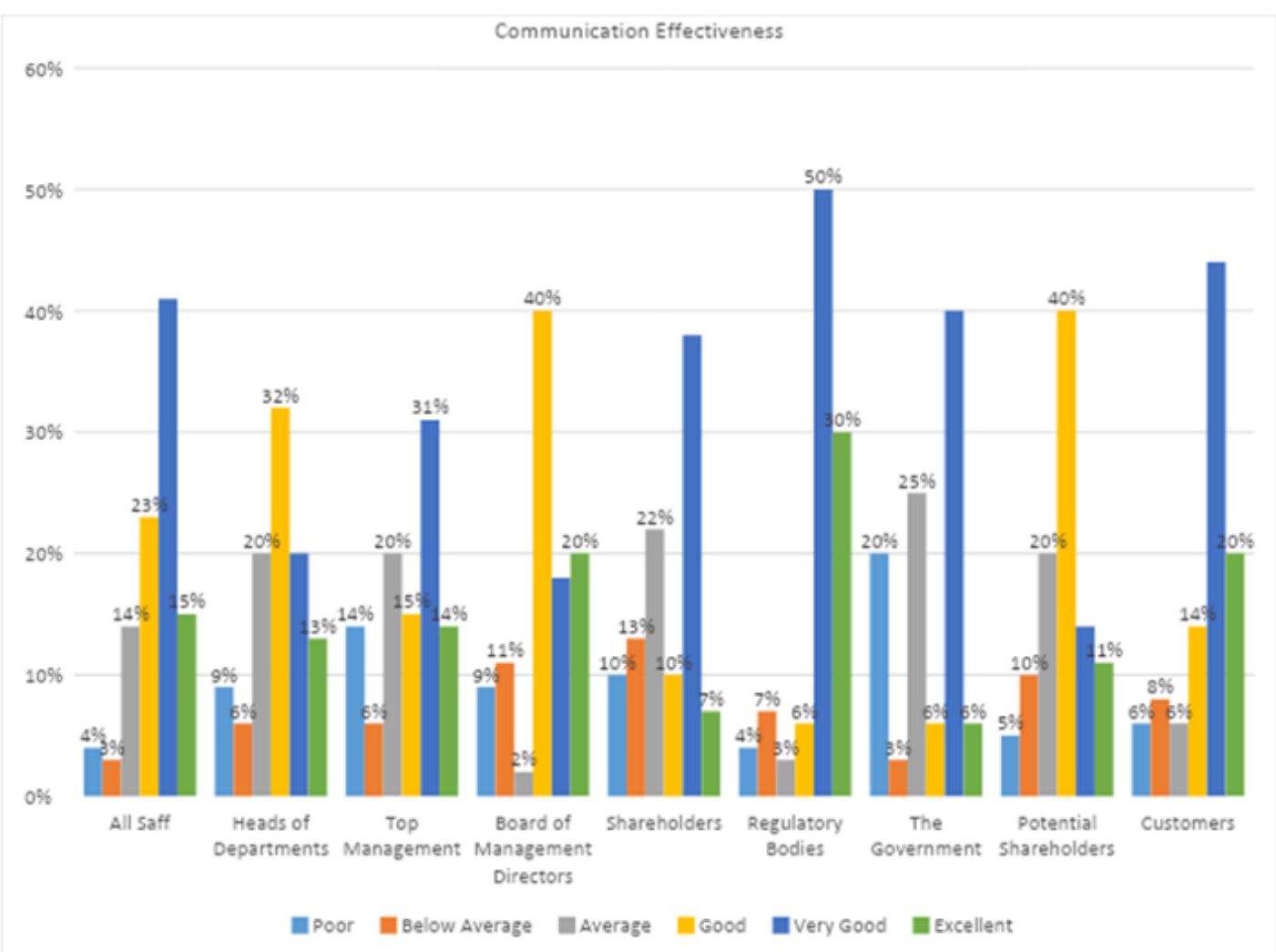

Co-Operatives Effectiveness in Communicating with the Publics

\subsection{Co-Operatives Use of Communication Channels}

According to the study on use of organization's website, $30 \%$ of the respondents stated it was good, $21 \%$ stated excellent, $17 \%$ very good, $16 \%$ average, $11 \%$ poor and $5 \%$ below average. That a small number rate their website as poor and below average; combined percentage of $16 \%$ however should not be taken for granted. This percentage bearing in mind the technologically constantly changing world should be taken as a matter of concern. However the other $84 \%$ that rate their websites as above average is a pointer towards improvement. Perhaps further studies need to be carried out in this respect to find out whatever gaps are in the area.

On social media sites, the researchers found out that $38 \%$ indicated very good, $30 \%$ good, $20 \%$ excellent, $6 \%$ average, $4 \%$ below average and $2 \%$ poor. These findings, the researchers deduce that 
cooperatives in Meru County have adopted the use of social media sites as channels of communications both for internal and external publics. The researchers can deduce that social media are a commonly used tool because of availability of gadgets and internet. In that most of the social media applications are easy to navigate, information is easy and simple to comprehend, anyone can air their opinions and also the tools for accessing the sites especially mobile telephone are, most of them internet enabled.

On direct telephone calls, $40 \%$ indicated very good, $32 \%$ good, $11 \%$ average, $8 \%$ excellent, $7 \%$ poor and $2 \%$ below average. This is a rather traditional but effective method of communication. It has however grown and developed with time owing to accessibility and penetration of mobile telephone is rural areas. About $72 \%$ of the respondents termed it has very good and excellent. This is perhaps of the personal touch and immediacy in getting feedback. This method is not limited to literacy levels of the users and seems to be the most effective according to the research findings.

On direct emails, $37 \%$ cited good, $33 \%$ very good, $11 \%$ average, $8 \%$ poor, $7 \%$ average and $4 \%$ below average. On bulk SMS services, $29 \%$ stated very good, $23 \%$ poor, $18 \%$ below average, $12 \%$ good, $10 \%$ excellent, $8 \%$ average. On other communication channels, $31 \%$ cited poor, $23 \%$ good, $14 \%$ below average, $12 \%$ average, $11 \%$ very good and $9 \%$ excellent.

The researchers can conclude that Social media communication channels are vibrant in most of the co-operative societies. This is used to communicate with internal and external clients of the cooperatives. Such sites can also be used to reach out to both members and non-members of the cooperative society.

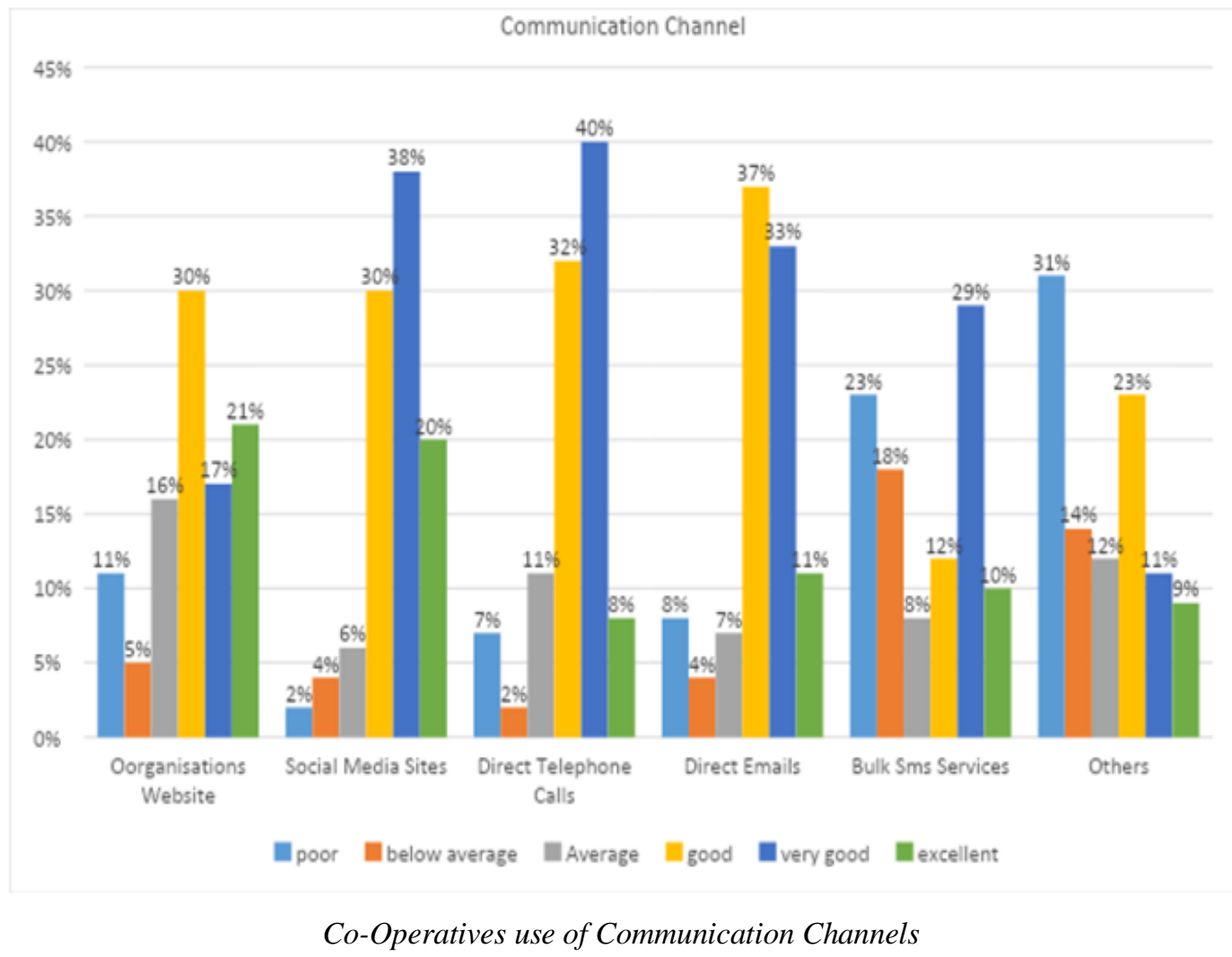

\subsection{Communication Channels used}

From this study, it has been found out that co-operatives use various channels of communications. The most commonly used include dedicated telephone line, social media and dedicated email. Some also have a complaints register and websites as a channel of communication. According to the study, communication channels used, $79 \%$ of the respondents stated that their organizations used dedicated official email while $21 \%$ cited not at all, $83 \%$ indicated they used social media while 17 stated not all, $48 \%$ stated they used websites while $52 \%$ indicated not at all, $89 \%$ stated they used dedicated telephone line while $11 \%$ cited not at all, $51 \%$ stated they used complaints register while $49 \%$ stated not at all and lastly $23 \%$ cited that they used other forms of communication while $77 \%$ indicated not at all. 


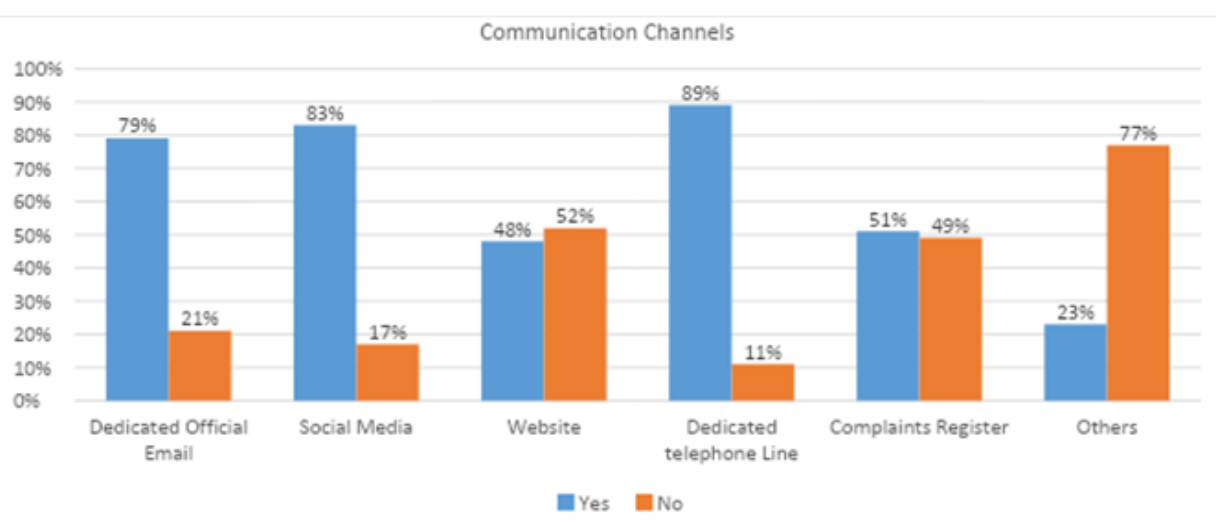

Communication Channels used by Cooperatives

Use of Website

\begin{tabular}{|l|l|l|l|l|l|}
\hline \multicolumn{2}{|c|}{ Frequency } & \multicolumn{1}{c|}{ Percent } & \multicolumn{1}{c|}{ Valid Percent } & \multicolumn{1}{c|}{ Cumulative Percent } \\
\hline \multirow{3}{*}{ Valid } & Yes & 40 & 63.5 & 63.5 & 63.5 \\
\cline { 2 - 6 } & No & 23 & 36.5 & 36.5 & 100.0 \\
\cline { 2 - 6 } & Total & 63 & 100.0 & 100.0 & \\
\hline
\end{tabular}

According to the study, the researchers found out that $63.5 \%$ of the respondents who were the majority stated that their co-operatives had a website while 36.5 cited not at all. It can be deduced that co-operatives may not be having websites because of the technical support and the IT infrastructure required to build a website and maintain it. Also the human resource required and skills may not be at the reach of the co-operatives and also the availability of the internet bandwidth. With a huge percentage of the co-operatives literally operating without a website, intervention measures perhaps need to be put into place by policy makers to address this gap.

Use of Social Networking Sites to Enhance Uptake of Services

\begin{tabular}{|l|l|l|l|l|l|}
\hline \multicolumn{2}{|c|}{} & Frequency & Percent & Valid Percent & Cumulative Percent \\
\hline \multirow{3}{*}{ Valid } & Yes & 37 & 58.7 & 58.7 & 58.7 \\
\cline { 2 - 6 } & No & 26 & 41.3 & 41.3 & 100.0 \\
\cline { 2 - 6 } & Total & 63 & 100.0 & 100.0 & \\
\hline
\end{tabular}

According to the respondents, $58.7 \%$ who were the majority stated they used social networking sites to enhance uptake of services while $41.3 \%$ stated not at all. Co-operatives use social media sites for various reasons. This question tested, specifically the use of social networking sites to enhance uptake of co-operative services. This means the social networking sites are populated with co-operative information that would enhance uptake of the services.

The $42.3 \%$ of the respondents who use social networking sites not for enhancing increased uptake of co-operative services perhaps us social media for other information purposes.

\subsection{Social Networking Sites Used by Cooperatives}

According to the study, $58 \%$ of the respondents who were the majority stated that they used Facebook as a networking site while $42 \%$ stated not at all, 51\% indicated that they used twitter while $49 \%$ indicated not at all, $85 \%$ stated they used Whatsapp while $15 \%$ indicated not at all, $21 \%$ cited they used LinkedIn while 79\% stated not at all, 33.1\% indicated they used Instagram while 66.9\% cited not at all and lastly $46 \%$ stated they used other networking sites while $54 \%$ indicated not at all.

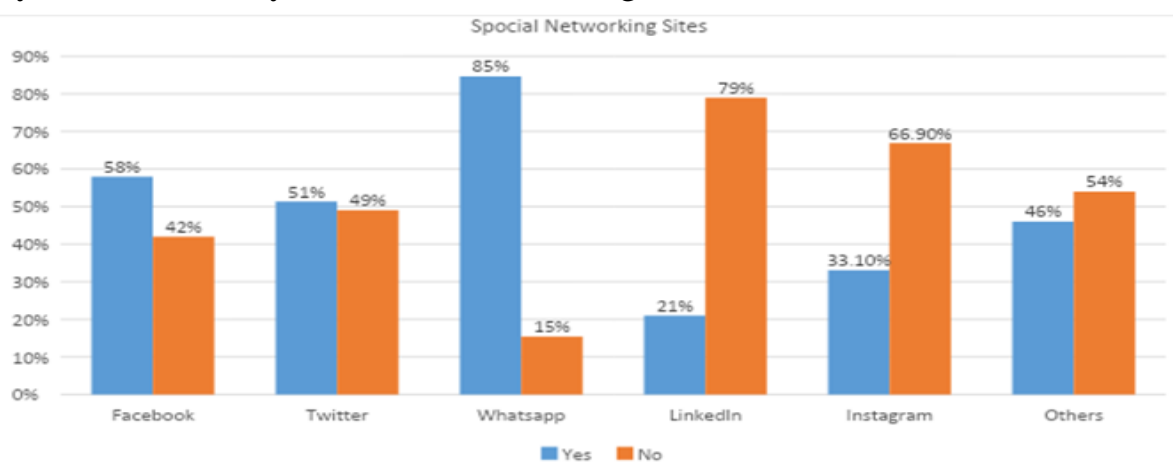

Utilization of Social Networking Sites by Cooperatives 


\subsection{Website Aspects and Efficacy}

According to the study on website aspects, on the general look of the website, $30 \%$ stated it was very good, $24 \%$ cited average, $17 \%$ good, $12 \%$ poor, $9 \%$ excellent and $8 \%$ below average. On website regular updating $32 \%$ cited it was poor, $20 \%$ average, $16 \%$ good, $13 \%$ very good, $12 \%$ below average and $7 \%$ excellent. On factual website information $40 \%$ indicated very good, $21 \%$ good, $15 \%$ average, $15 \%$ excellent, $6 \%$ below average and lastly $3 \%$ poor. On the website being rich in information and content $36 \%$ cited average, $20 \%$ below average, $13 \%$ poor, $12 \%$ good, $11 \%$ excellent and $8 \%$ very good. On interactivity on website $40 \%$ indicated average, $23 \%$ below average, $18 \%$ good, $8 \%$ excellent, $7 \%$ poor and $4 \%$ very good. On the website being educative $35 \%$ cited good, $20 \%$ average, $15 \%$ excellent, $12 \%$ very good, $10 \%$ poor and $8 \%$ below average. On ease to navigate $30 \%$ cited below average, $27 \%$ average, $14 \%$ good, $13 \%$ very good, $10 \%$ excellent and $6 \%$ poor.

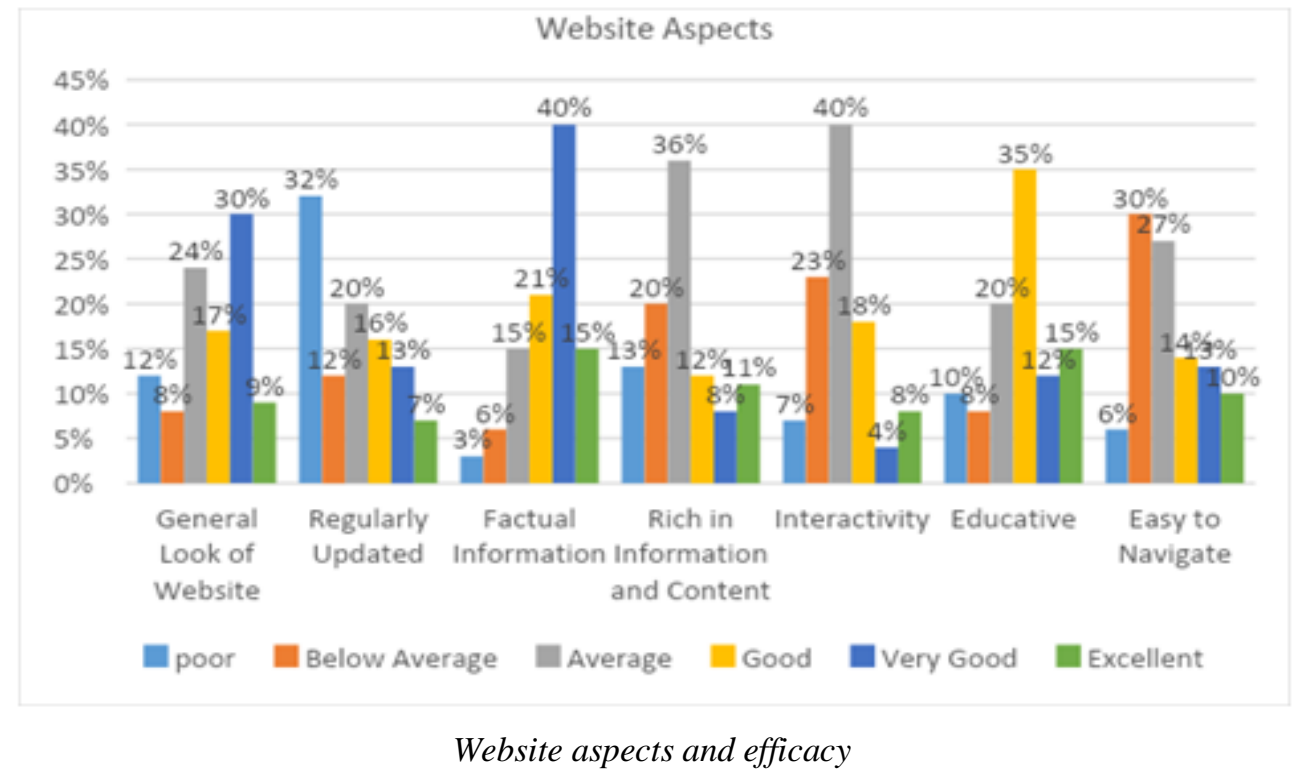

\subsection{New Media Communication Tools}

According to the study on the use of new media communication tools, $38 \%$ of the respondents cited the use of website was average, $22 \%$ cited good, $20 \%$ below average, $8 \%$ very good, $7 \%$ poor and $5 \%$ excellent. On use of official emails, $32 \%$ of the respondents indicated it was good, $25 \%$ very good, $21 \%$ average, $13 \%$ excellent, $6 \%$ poor and $3 \%$ below average. On the use of Facebook, $29 \%$ indicated average, $24 \%$ good, $20 \%$ very good, $14 \%$ excellent, $9 \%$ poor and $4 \%$ below average. On use of Twitter $25 \%$ cited below average, $22 \%$ cited poor, $20 \%$ good, $19 \%$ average, $11 \%$ excellent and $3 \%$ very good. On use of Whatsapp $43 \%$ cited very good, $24 \%$ excellent, $18 \%$ good, $7 \%$ average, 5\% poor and $3 \%$ below average.

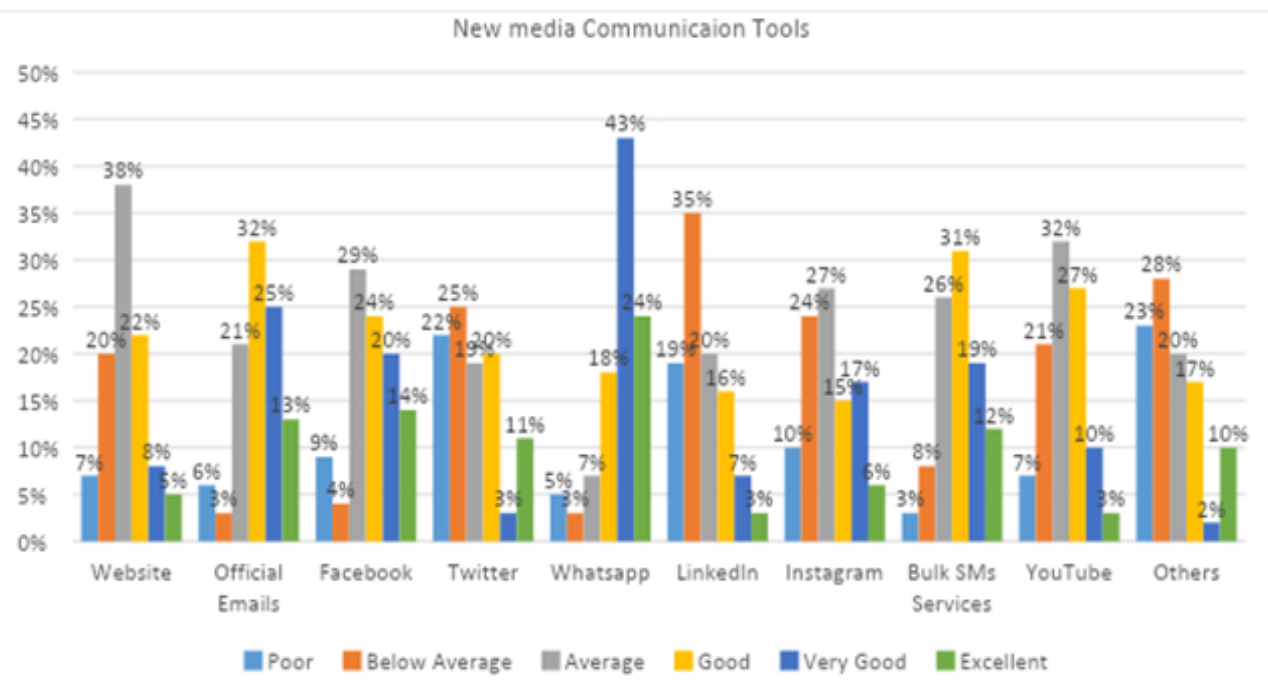

New Media Communication Tools by Cooperatives 
On use of LinkedIn 35\% cited below average, $20 \%$ indicated average, $19 \%$ poor, $16 \%$ good, $7 \%$ very good and 3\% excellent. On the use of Instagram 27\% cited average, $24 \%$ below average, $17 \%$ very good, $15 \%$ good, $10 \%$ poor and $6 \%$ excellent. On the use of bulk SMS services, $31 \%$ indicated good, $26 \%$ average, $19 \%$ very good, $12 \%$ excellent, $8 \%$ below average and $3 \%$ poor. On the use of YouTube, $32 \%$ of the respondents stated average, $27 \%$ good, $21 \%$ below average, $10 \%$ very good, $7 \%$ poor and $3 \%$ excellent. On the use of other new networking sites $28 \%$ of the respondents stated it was below average, $23 \%$ indicated poor, $20 \%$ good, $17 \%$ very good, $10 \%$ excellent and $2 \%$ very good.

Access to Reliable Internet connections

\begin{tabular}{|l|l|l|l|l|}
\hline & Frequency & Percent & Valid Percent & Cumulative Percent \\
\hline Yes & 50 & 79.4 & 79.4 & 79.4 \\
\hline No & 13 & 20.6 & 20.6 & 100.0 \\
\hline Total & 63 & 100.0 & 100.0 & \\
\hline
\end{tabular}

3.6.1. Access to Reliable Internet Connection at your Workstation

According to the study $79.4 \%$ of the respondents who were the majority agreed that they have access to reliable internet connections at work while $20.6 \%$ stated they don't have.

Specialized Mobile Application to Enhance Uptake of Services

\begin{tabular}{|l|l|l|l|l|l|}
\hline \multicolumn{2}{|c|}{} & Frequency & Percent & Valid Percent & Cumulative Percent \\
\hline \multirow{3}{*}{ Valid } & Yes & 34 & 54.0 & 54.0 & 54.0 \\
\cline { 2 - 6 } & No & 29 & 46.0 & 46.0 & 100.0 \\
\cline { 2 - 6 } & Total & 63 & 100.0 & 100.0 & \\
\hline
\end{tabular}

According to the study, 54\% of the respondents who were the majority agreed that their Co-operative societies had specialized mobile applications to enhance uptake of the services while $46 \%$ indicated not at all.

3.6.2. New Media Tools in Fostering Competitive Positioning

\begin{tabular}{|l|l|l|l|l|}
\hline & Frequency & Percent & Valid Percent & Cumulative Percent \\
\hline Yes & 37 & 58.7 & 58.7 & 58.7 \\
\hline No & 16 & 25.4 & 25.4 & 84.1 \\
\hline Not sure & 10 & 15.9 & 15.9 & 100.0 \\
\hline Total & 63 & 100.0 & 100.0 & \\
\hline
\end{tabular}

\subsubsection{New Media as a Communication Tool in Foster a Competitive Positioning}

According to the study, $58.7 \%$ of the respondents who were the majority stated that the new media as a communication tool fostered a competitive positioning for their Co-operative societies, $25.4 \%$ indicated not at all and lastly $15.9 \%$ indicated they were not sure.

Use of New Communication Tools on Customer Management

\begin{tabular}{|l|l|l|l|l|}
\hline & Frequency & Percent & Valid Percent & Cumulative Percent \\
\hline Effective & 24 & 38.1 & 38.1 & 38.1 \\
\hline Not effective & 7 & 11.1 & 11.1 & 49.2 \\
\hline Exploitative & 16 & 25.4 & 25.4 & 74.6 \\
\hline None of the above & 16 & 25.4 & 25.4 & 100.0 \\
\hline Total & 63 & 100.0 & 100.0 & \\
\hline
\end{tabular}

\subsubsection{Use of New Media as a Communication Tool on Customer Management}

According to the study, $38.1 \%$ indicated that the current use of new media as a communication tool by the organization on customer management was effective, $25.4 \%$ indicated it was exploitive, $25.4 \%$ indicated it had no effect and $11.1 \%$ stated not at all.

ICT Innovations on Youth Customer Growth

\begin{tabular}{|l|l|l|l|l|}
\hline & Frequency & Percent & Valid Percent & Cumulative Percent \\
\hline Yes & 44 & 69.8 & 69.8 & 69.8 \\
\hline No & 10 & 15.9 & 15.9 & 85.7 \\
\hline I don't know & 9 & 14.3 & 14.3 & 100.0 \\
\hline Total & 63 & 100.0 & 100.0 & \\
\hline
\end{tabular}




\subsubsection{Use of ICT Innovations to Increase Youth Customer Growth}

According to the respondents, $69.8 \%$ of the respondents who were the majority stated that the use of ICT innovations helped to increase customer growth especially the youth, $15.9 \%$ cited not at all and $14.3 \%$ indicated that they didn't know.

ICT innovation(s) adopted by Co-operative society

\begin{tabular}{|l|l|l|l|l|}
\hline & Frequency & Percent & Valid Percent & Cumulative Percent \\
\hline Bulk sms & 1 & 1.6 & 1.6 & 1.6 \\
\hline Facebook groups & 15 & 23.8 & 23.8 & 25.4 \\
\hline Mobile Banking & 7 & 11.1 & 11.1 & 36.5 \\
\hline n/a & 3 & 4.8 & 4.8 & 41.3 \\
\hline Online loans application & 1 & 1.6 & 1.6 & 42.9 \\
\hline Social media & 18 & 28.6 & 28.6 & 71.4 \\
\hline Whatsapp and Facebook groups & 1 & 1.6 & 1.6 & 73.0 \\
\hline Whatsapp groups & 17 & 27.0 & 27.0 & 100.0 \\
\hline Total & 63 & 100.0 & 100.0 & \\
\hline
\end{tabular}

According to the study on recent innovations, $28.6 \%$ of the respondents who were the majority argued that used social media platforms, $27.0 \%$ stated Whatsapp groups, $23.8 \%$ indicated facebook groups, $11.1 \%$ stated Mobile banking, 4.8\% stated not applicable, $1.6 \%$ stated bulks SMS, online loan application and both Whatsapp and Facebook groups.

\subsection{Internet Series}

According to the study on internet series used in the Cooperatives, 54\% stated they used mobile subscriptions while $46 \%$ stated not at all, $53.2 \%$ indicated they used fiber optic connections while $46.8 \%$ indicated not at all, $41.3 \%$ stated they used broadband internet connections while $58.7 \%$ indicated not at all and lastly $44 \%$ cited that they used other internet series while $56 \%$ stated not at all.

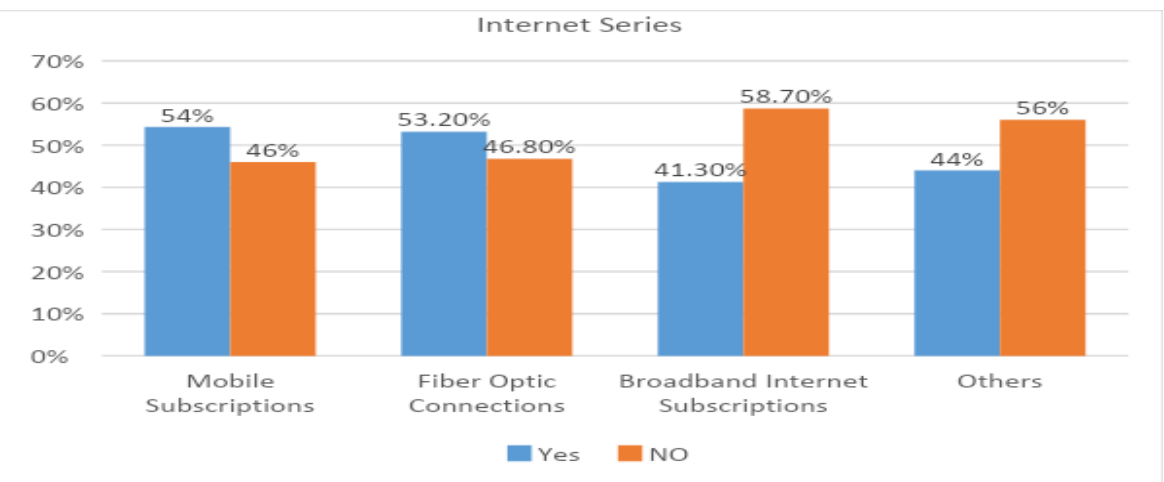

Internet Series

\subsection{Co-Operative Policies}

According to the study on the policies, $62.30 \%$ indicated their cooperatives had communication policies while $37.70 \%$ cited not at all, $48.90 \%$ agreed they had ICT policies while $51.10 \%$ stated not at all, $72 \%$ cited they had membership policy while $28 \%$ cited not at all and lastly $52.40 \%$ indicated that they had marketing policies while $47.60 \%$ indicated not at all.

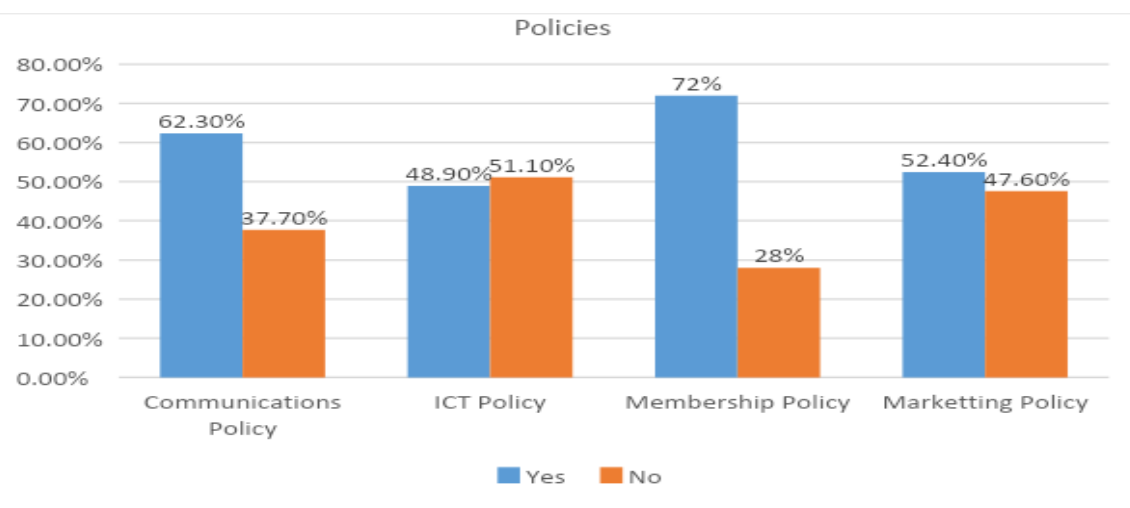

Human Resource and Other Policies 


\section{REGRESSION ANALYSIS OF THE FINDINGS}

The researcher conducted a multiple linear regression analysis so as to assess the adoption of new communication technologies for co-operative development in Kenya and the four independent factors namely: Communication Process (CP), Efficacy (EF), ICT Infrastructure (IF) and Human Resource Policies (HRP)

The regression equation was

$$
\mathrm{Y}=\beta 0+\beta 1 \mathrm{X} 1+\beta 2 \mathrm{X} 2+\beta 3 \mathrm{X} 3+\varepsilon
$$

Whereby $\quad \mathrm{Y}=$. Co-operative information $(\mathrm{CI})$

$\mathrm{X}_{1}=$ Communication Process $(\mathrm{CP})$

$\mathrm{X}_{2}=$ Efficacy $(\mathrm{EF})$

$\mathrm{X}_{3}=\mathrm{ICT}$ Infrastructure (IF)

$\mathrm{X}_{4}=$ Human Resource Policies (HRP)

Table4.21. Model Summary

\begin{tabular}{|l|l|l|l|l|}
\hline Model & R & R Square & Adjusted R Square & Standard Error of the Estimate \\
\hline $\mathbf{1}$ & $\mathbf{0 . 8 4 3}$ & $\mathbf{0 . 7 4 2}$ & $\mathbf{0 . 7 2 4}$ & $\mathbf{0 . 4 2 1 6}$ \\
\hline
\end{tabular}

a. Predictors: (Constant), Communication Process (CP), Efficacy (EF), ICT Infrastructure (IF) and Human Resource Policies (HRP)

b. Independent variable: Co-operative information

The study used the R square. The R Square is called the coefficient of determination and tells us how Co-operative information varied with Communication Process (CP), Efficacy (EF), ICT Infrastructure (IF) and Human Resource Policies (HRP). The four independent variables that were studied explain $74.2 \%$ of the factors are affected by Co-operative information as represented by $\mathrm{R}$ Squared (Coefficient of determinant). This therefore means that other factors not studied in this research contribute $25.8 \%$ of the factors affected by Co-operative information among youths in Meru.

ANOVA

\begin{tabular}{|l|l|r|r|r|r|c|}
\hline Model & & Sum of Squares & df & Mean Square & F & Sig. \\
\hline \multirow{4}{*}{1} & Regression & 11.72 & 9 & 1.302 & 44.231 & $.000(\mathrm{a})$ \\
\cline { 2 - 7 } & Residual & 3.432 & 52 & 0.066 & & \\
\cline { 2 - 8 } & Total & $\mathbf{1 5 . 1 5 2}$ & $\mathbf{6 1}$ & & & \\
\hline
\end{tabular}

a) Predictors: (Constant), Communication Process (CP), Efficacy (EF), ICT Infrastructure (IF) and Human Resource Policies (HRP)

a. Independent Variable: Co-operative information (CI)

The study used ANOVA to establish the significance of the regression model from which an fsignificance value of $\mathrm{p}$ less than 0.05 was established. The model is statistically significant in predicting communication Process (CP), Efficacy (EF), ICT Infrastructure (IF) and Human Resource Policies (HRP) are affected by by Co-operative information among youths in Meru. This shows that the regression model has a less than 0.05 likelihood (probability) of giving a wrong prediction. This therefore means that the regression model has a confidence level of above 95\% hence high reliability of the results.

\subsection{Coefficients Results}

\begin{tabular}{|l|l|l|l|l|l|}
\hline & Unstandardized Coefficients & Standardized Coefficients & $\mathrm{t}$ & Sig. \\
\hline & $\mathrm{B}$ & Std. Error & Beta & & \\
\hline (Constant) & 0.116 & .186 & & 0.623 & .535 \\
\hline Communication Process & 0.577 & .068 & .559 & 8.478 & .000 \\
\hline Efficacy & 0.157 & .043 & .257 & 3.676 & .036 \\
\hline ICT Infrastructure & 0.082 & .042 & .301 & 2.252 & .020 \\
\hline Human Resource Policies & 0.021 & .002 & .245 & 6.906 & .001 \\
\hline
\end{tabular}


b. Predictors: (Constant), ), Communication Process (CP), Efficacy (EF), ICT Infrastructure (IF) and Human Resource Policies (HRP)

c. Independent Variable: Co-operative information (CI)

The established regression equation was

$\mathrm{Y}=0.116+0.577 \mathrm{X}_{1}+0.157 \mathrm{X}_{2}+0.082 \mathrm{X}_{3}+0.021 \mathrm{X}_{4}+\varepsilon$

The regression equation above has established that holding all factors (predicting communication Process (CP), Efficacy (EF), ICT Infrastructure (IF) and Human Resource Policies (HRP)) constant, factors influenced by Co-operative information and hence affects youths performance in Meru will be 0.116 . The findings presented also shows that taking all other dependent variables at zero, a unit increase in Co-operative information will lead to a 0.577 increase in the scores of communication process. A unit increase in Co-operative information will lead to a 0.157 increase in Efficacy. On the other hand, a unit increase in Co-operative Information will lead to a 0.082 increase in the scores of the ICT Infrastructure; and a unit increase in Co-operative Information will lead to a 0.021 increase in the scores of Human Resource Policies. This infers that Communication process is influenced by Cooperative information among youths in Meru most followed by Efficacy, ICT Infrastructure and then Human resource policies. The study also established a significant relationship between Co-operative information among youths in Meru and the dependent variables; Communication process $(p=0.00<0.05)$, Efficacy $(p=0.036<0.05)$, ICT Infrastructure $(p=0.20<0.05)$ and Human resource policies $(p=0.001<0.05)$ as shown by the $p$ values. The researcher dropped the regression model because $\mathrm{p}>0.5$ and $\mathrm{t}<1.96$. Therefore the restated model is as follows:

$\mathrm{Y}=0.577 \mathrm{X}_{1}+0.157 \mathrm{X}_{2}+0.082 \mathrm{X}_{3}+0.021 \mathrm{X}_{4}+\varepsilon$

\subsection{Non-Parametric Correlation}

A Spearman correlation is used when one or both of the variables are not assumed to be normally distributed. The values of the variables were converted in ranks and then correlated. The study correlated communication process, Efficacy, ICT Infrastructure and Human resource Policies under the assumption that both of these variables are normal and interval.

\subsection{Correlations}

\begin{tabular}{|c|c|c|c|c|c|c|}
\hline & & & $\begin{array}{l}\text { Communication } \\
\text { Process }\end{array}$ & Efficacy & $\begin{array}{l}\text { ICT } \\
\text { Infrastructure }\end{array}$ & $\begin{array}{l}\text { Human Resource } \\
\text { Policies }\end{array}$ \\
\hline \multirow{12}{*}{$\begin{array}{l}\text { Spearman's } \\
\text { rho }\end{array}$} & Communication & Correlation & 1.000 & .617 & .547 & .667 \\
\hline & Process & Coefficient & & .000 & .000 & .000 \\
\hline & & $\begin{array}{l}\text { Sig. (2-tailed) } \\
\mathrm{N}\end{array}$ & 61 & 61 & 61 & 61 \\
\hline & Efficacy & Correlation & .617 & 1.000 & .437 & .235 \\
\hline & & Coefficient & .000 & & .000 & .001 \\
\hline & & $\begin{array}{l}\text { Sig. (2-tailed) } \\
\mathrm{N}\end{array}$ & 61 & 61 & 61 & 61 \\
\hline & ICT Infrastructure & Correlation & .547 & .437 & 1.000 & .441 \\
\hline & & Coefficient & .000 & .000 & & .002 \\
\hline & & $\begin{array}{l}\text { Sig. (2-tailed) } \\
\mathrm{N}\end{array}$ & 61 & 61 & 61 & 61 \\
\hline & Human Resource & Correlation & .667 & .235 & .441 & 1.000 \\
\hline & Policies & Coefficient & .000 & .000 & .000 & \\
\hline & & $\begin{array}{l}\text { Sig. (2-tailed) } \\
\mathrm{N}\end{array}$ & 61 & 61 & 61 & 61 \\
\hline
\end{tabular}

The results suggest that the relationship between Communication Process and Efficacy (rho $=0.617, \mathrm{p}$ $=0.000$ ) is statistically significant. Communication process and ICT Infrastructure had a rho of 0.547 and a $\mathrm{p}$ value of 0.000 therefore denoting statistical significance. Similarly, the Communication Process and Human Resource Policies posted a rho of 0.667 with a $\mathrm{p}$ value of 0.000 therefore providing a statistical significance. Efficacy and ICT Infrastructure had a rho of $0.437, \mathrm{p}=0.000$ further pointing to a statistical significance. On the same note, Efficacy and Human Resource Policies correlated at $r h o=0.235$ and $\mathrm{p}=0.001$. This therefore is statistically significant. Finally, the ICT Infrastructure and Human Resource Policies stood at a correlation of rho $=0.441$ and $p=0.002$ revealing statistical significance. 


\section{CONCLUSION AND RECOMMENDATIONS}

\subsection{Communication Process}

From this study, the findings indicate that majority of co-operatives use various channels of communications. The most commonly used include dedicated telephone lines, social media and dedicated email. It has further been found out that majority of the respondents stated that their cooperatives had a website. From this it can be concluded that the social networking sites are populated with co-operative information that would enhance uptake of the services.

It was found out that cooperatives leverage on ICT innovations to increase customer growth especially the youth. According to the study on recent innovations, majority of the respondents argued that they used social media platforms like Whatsapp groups, Facebook groups, Mobile banking, bulks SMS and online loan application. Further, there are several internet series used in the Cooperatives, majority of the respondents stated they used mobile subscriptions, they used fiber optic connections, they used broadband internet connections and lastly that they used other internet series.

It is recommended that Co-operative societies need to come up with intervention measures to address their presence on social media sites. Such interventions may include having social media policies to the effect. Further the researchers recommend recruitment of human resource persons with ability to handle the social media; these are staff who would be fully dedicated to handling and manning social round the clock. We also recommend that messages sent out to the social media need to be intensified in terms of frequency and response to queries need to have zero lifespan

Co-operatives invest in ICT infrastructure especially in provision of computers and other associated hardware. This will enable their staff to have their operations integrated and open opportunities for online information provision and communication especially on emails.

\section{REFERENCES}

[1] Beard, C. A., (1927). 'Time, Technology, and the Creative Spirit in Political Science'. In The American Political Science Review. Vol. 21, No. 1. NewYork: American Political Science Association.

[2] Benkler, Y. (2007), The Wealth of Networks: How Social Production Transforms Markets and Freedom, New Haven, CT: Yale University Press.

[3] Bernasek, A. and Mongan, D. T. (2015), All You Can Pay: How Companies Use Our Data to Empty Our Wallets, New York: Nation Books.

[4] Boyd, D. M. and Nicole B. Ellison, "Social Network Sites: Definition, History, and Scholarship," Journal of Computer Mediated Communication 13, no. 1 (2008): 211.

[5] Creswell, J. W. (1994). Research design. Thousand Oaks, CA: Sage.

[6] Crowther, D. \& Lancaster, G. (2008), Research Methods (2nd Edition), Amazon

[7] Curl, J. (2012), For All the People: Uncovering the Hidden History of Cooperation, Cooperative Movements, and Communalism in America, 2nd ed., Oakland, CA: PM Press.

[8] Debra Corey (2016), Effective HR Communication: A Framework for Communicating HR programmes with impacts: Amazon digital services

[9] Ebert J.D, (2011), The New Media Invasion; New Media Technologies And The World The Unmake, McFarland \& company, Inc., publishers, Jefferson, north Carolina and London

[10] FSD, Kenya 2015: http://fsdkenya.org/an-overview-of-m-pesa/

[11] Griffin, E., Et Al (2014), A First Look at Communication Theory. McGraw-Hill, USA k

[12] Guba, E. G., \& Lincoln, Y. S. (2005). Paradigmatic controversies, contradictions, and emerging influences. In N. K. Denzin and Y. S. Lincoln (Eds.), The Sage Handbook of Qualitative Research (3rd ed.) (pp. 191-215). Thousand Oaks, CA: Sage.

[13] Kelly, M. (2012), Owning Our Future: The Emerging Ownership Revolution, Oakland, CA: BerretKoehler Publishers.

[14] Kobia S.K. (2011), The Co-operative Movement in Kenya, Challenges and Opportunities; Lukiko consulting Publishers, Nairobi

[15] Kostakis, V. and Bauwens, M. (2014), Network Society and Future Scenarios for a Collaborative Economy, New York: Palgrave Macmillan.

[16] Kothari, C. R., Ramanna, K., \& Skinner, D. J. (2010).Implications for GAAP from an analysis of positive research in accounting Journal of Accounting and Economic 
[17] Kunz, William M. (2006). Culture Conglomerates: Consolidation in the Motion Picture and Television Industries. Publisher: Rowman \& Littlefield Publishers, Inc.

[18] Kurzweil, R. (1999). The Age of Spiritual machines. Chapter 1: 2009. USA: Viking Adult

[19] Lev Manovich, (2001): The Language of New Media, The Library of Congress, USA

[20] McGregor, S.L.T., \& Murnane, J. A. (2010). Paradigm, methodology and method: Intellectual integrity in consumer scholarship. International Journal of Consumer Studies, 34(4), 419-427

[21] McQuail, Denis (2010), McQuails's Mass Communication Theory (sixth edition)

[22] McQuail, Denis (ed.) (2002), McQuail's reader in mass communication theory Sage, London

[23] Robert K. Logan, (2010): Understanding New Media: Extending Marshall McLuhan., Peter Lang, USA

[24] Seel, P. B., (2012). Digital Universe: The Global Telecommunication Revolution. West Sussex, UK: Wiley-Blackwell.

[25] Siapera, E., Understanding New Media (Thousand Oaks, CA: Sage, 2012), 3.

[26] Silberman, MS (2016), Reading Elinor Ostrom in Silicon Valley: Exploring Institutional Diversity on the Internet; ACM Conference Paper November 13-16, Sanibel Island, FL

[27] Smith \& Marx, Merrit Roe \& Leo (June 1994). Does Technology Drive History? The Dilemma of Technological Determinism. The MIT Press. ISBN 978-0262691673.

[28] Steven Deller et al, (2009), Research on the Economic Impact of Cooperatives: University of Wisconsin Center for Cooperatives

[29] Taylor, S. J., \& Bogdan, R. (1998). Introduction to qualitative research methods. Hoboken, NJ: Wiley.

[30] Vinge, V., (1993). 'The coming technological singularity: how to survive in the post-human era'. San Diego State University, California. In NASA Conference Publication 10129. Vision-21: Interdisciplinary Science and Engineering in the Era of Cyberspace. (pp. 274) Westlake, Ohio.

[31] ITU (International Telecommunication Union) (2010) ICT Statistics Newslog - National survey shows Kenyan Internet market heading towards "critical mass" http://www.itu.int/ITU-D/ict/newslog/ National+ Survey+Shows+Kenyan+Internet+Market+Heading+Towards+Critical+Mass.aspx (viewed 6.6 2013)

[32] Kaplan, M. and Michael Haenlein (2010) 'Users of the world, unite! The challenges and opportunities of Social Media,' Business Horizons 53. pp 59-68.

[33] Klaehn, Jeffrey (2002) 'A critical Review and Assessment of Herman and Chomsky’s Propaganda Model,' European Journal of Communication, 17, pp.147-174.

[34] Mäkinen, Maarit and Wary Wangu Kuira (2008) 'Social Media and Post-election Crisis in Kenya,' Press/ Politics, 13(3).

[35] Murlidhar, Sid (2010) The Facebook Blog 'Fast and Free Facebook Mobile Access with 0.facebook.com' https://blog.facebook.com/blog.php?post=391295167130 (viewed 15.8. 2014)

Citation: Mwongela Francis, et.al. "Assessing Adoption of New Communication Technologies for CoOperative Development in Kenya". International Journal of Media, Journalism and Mass Communications (IJMJMC), vol 5, no. 3, 2019, pp. 1-12 doi: http://dx.doi.org/10.20431/2455-0043.0503001

Copyright: (C) 2019 Authors. This is an open-access article distributed under the terms of the Creative Commons Attribution License, which permits unrestricted use, distribution, and reproduction in any medium, provided the original author and source are credited. 